Viçosa, MG, DEA/UFV - DOI: 10.13083/reveng.v29i1.12621

v.29, p.389-404, 2021

\title{
CREATION OF AN ENVIRONMENTAL PROTECTION AREA IN A PUBLIC SUPPLY SOURCE: POSSIBILITIES AND CHALLENGES IN CIANORTE-PARANÁ
}

\author{
Márcio Santos da Silva ${ }^{1}$ (D), Cristiane Kreutz ${ }^{2}$ iD, Robertson Fonseca de Azevedo ${ }^{3}$ (D) \& Maristela Denise Moresco Mezzomo ${ }^{2}$ \\ 1 - Paraná Sanitation Company (SANEPAR), Cianorte, Paraná, Brazil \\ 2 - Federal University of Technology - Parana, Academic Department of Environmental, Campo Mourão, Paraná, Brazil \\ 3 - Paraná State Public Ministry, 42nd Judiciary Section of Paranavaí, Paranavaí, Paraná, Brazil
}

Keywords:

Environmental quality

Hydrographic basin

Sustainability

\section{ABSTRACT}

This work analyzed the contribution that the creation of Environmental Protection Areas (EPA) may bring to the conservation of hydrographic basins used as public water sources. The object of study of this work was the hydrographic basin of the Ligeiro River which, by 2022 onwards, will be the new source of public supply in the city of Cianorte-Paraná, replacing the hydrographic basin of the Bolívar stream. The latter has environmental impacts caused mainly by the expansion of urban areas and inadequate practice of land use, occupation, and management, which affects the population's supply, particularly on days with high levels of rainfall. The study area involved the creation of two municipal EPAs in the hydrographic basin of the Ligeiro River, located in the municipalities of Araruna and Cianorte, with areas of 209.76 $\mathrm{km}^{2}$ and $219.82 \mathrm{~km}^{2}$, respectively. It is believed that the creation of Environmental Protection Areas in the Ligeiro River hydrographic basin will also present challenges, but it will enable the conservation of natural resources and, especially, of water resources, given the quality of the water. It is expected that these actions will help to minimize or even prevent, in the future, the Ligeiro river hydrographic basin from being as or more impacted as the Bolivar stream basin.

Palavras-chave:

Bacia hidrográfica

Qualidade ambiental

Sustentabilidade
CRIAÇÃO DE ÁREA DE PROTEÇÃO AMBIENTAL EM MANANCIAL DE ABASTECIMENTO PÚBLICO: POSSIBILIDADES E DESAFIOS EM CIANORTEPARANÁ

\section{RESUMO}

Este trabalho analisou a contribuição que a criação de Áreas de Proteção Ambiental (APA) pode trazer para a conservação de bacias hidrográficas utilizadas como mananciais de abastecimento público. O objeto de estudo deste trabalho foi a bacia hidrográfica do rio Ligeiro que, a partir de 2022, será o novo manancial de abastecimento público da cidade de Cianorte-Paraná, em substituição à bacia hidrográfica do ribeirão Bolívar. Esta última apresenta impactos ambientais causados, principalmente, pela expansão urbana e prática inadequada do uso, ocupação e manejo do solo, o que compromete o abastecimento da população, sobretudo, em dias com altos índices de precipitação pluviométrica. A área de estudo envolveu a criação de duas APAs municipais na bacia hidrográfica do rio Ligeiro, sendo localizadas nos municípios de Araruna e Cianorte, com áreas $209,76 \mathrm{~km}^{2}$ e $219,82 \mathrm{~km}^{2}$, respectivamente. Acredita-se que a criação das Áreas de Proteção Ambiental na bacia hidrográfica do rio Ligeiro também apresentará desafios, mas possibilitará a conservação dos recursos naturais e, especialmente, dos recursos hídricos, tendo em vista a qualidade da água. Espera-se que essas ações auxiliem na minimização ou ainda evitem que, no futuro, a bacia hidrográfica do rio Ligeiro seja tão ou mais impactada quanto a bacia hidrográfica do ribeirão Bolívar. 


\section{INTRODUCTION}

Springs are the source or the origin of the water used for the supply, which may be surface water when it flows over the soil surface (streams, creeks, rivers, or lakes); underground water, when it comes from the interior of the earth's crust after infiltration (springs, shallow wells, deep wells, etc.), and may belong to the water table, which maintains atmospheric pressure and confined water table, where the water is under pressure between impermeable layers of the ground; and rainwater, when it comes from precipitation and is used before it reaches the earth's surface (BRASIL, 2006).

In the municipalities of the state of Paraná, water for human consumption has surface springs as its main source. Therefore, the availability of water, in many cases, is affected in terms of quantity and quality, particular because of the precariousness of the sanitation infrastructure; overexploitation of water resources; punctual and diffuse pollution from industrial and agricultural activities; disorderly occupation of the land, especially in vulnerable areas, such as permanent preservation areas; inadequate land use and management practices; soil degradation, water erosion and siltation of water bodies; removal of vegetation cover; among others (INSTITUTO ESTADUAL DO AMBIENTE, 2018).

Okawa et al. (2021) corroborate the aforesaid statement, particularly regarding the disorderly occupation of the hydrographic basin due to social and economic needs which violate the environmental conservationist aspect in the surroundings of springs where the native vegetation should be maintained as natural as possible and which is the result of the lack of specific legislation on land use and occupation. Therefore, analysis and interpretation of the environmental changes, having a hydrographic basin as the unit of study, becomes an important tool that may serve as a basis for environmental planning, as it allows knowing the real conditions of use and preservation of water resources (CHUEH, 2004).

Examples of environmental imbalance conditions in hydrographic basins are found in the Northwestern Paraná state, particularly in the municipalities of Umuarama, Paranavaí, and Cianorte. The first two have been facing issues caused by the degradation of their springs. However, to minimize these adverse effects on these territories, Environmental Protection Areas (EPAs) were created.

EPAs, following Law No. 9.985 of July 18, 2000, which established the National System of Nature Conservation Units (in Portuguese, SNUC), is classified as a Sustainable Use Unit which, according to the provisions of Article 15 , protect biological diversity, organize the occupation process and ensure the sustainability of the use of natural resources. Also, "respecting the constitutional limits, it can establish norms and restrictions for the use of a private property located in an Environmental Protection Area" (BRASIL, 2000).

The creation of an EPA means the establishment of zones for different uses that facilitate the monitoring of activities that intend to be settled within its limits. For Torres and Schiavetti (2005), this mechanism helps to organize territorial occupation and protect and conserve the most vulnerable ecosystems.

The experiences of the municipalities of Umuarama and Paranavaí have shown that this is an important strategy for the conservation of soil and water resources. Regarding Cianorte, the situation is slightly different, as the current source, Bolívar stream, does not have conservation strategies and, as an aggravating factor, the allocation flow is affected. Because of such problems and the impossibility of increasing the allocation flow, a new water supply will be implemented in the municipality, using the hydrographic basin of the Ligeiro river.

This study was developed based on these experiences, to analyze the situation in the city of Cianorte. As the current condition of the spring on the Bolívar stream does not allow the improvement of conservation actions, especially regarding the quality of raw water, it is understood that the new spring is fully capable of starting its activities in a well-planned manner, provided that efficient environmental management is adopted. Consequently, the creation of Environmental Protection Areas (EPAs) in the Ligeiro river basin is proposed, considering, mainly, the existing 
examples in the EPAs in the region's public water supply (Paranavaí and Umuarama).

It is understood that EPA in springs is an efficient tool to adapt anthropic activities, in order to avoid environmental problems arising from the disorderly land use, as well as to promote the sustainable use of water resources, guaranteeing the quantity and quality of water for the population.

\section{MATERIAL AND METHODS}

The methodological aspects involved bibliographical research on the main topics covered (EPA, springs, raw water quality), in scientific articles, federal legislation, and documents from official agencies; survey of data and information on EPAs and springs on the websites of official agencies (city halls and state environmental agency); research on the environmental components of the studied basin (geology, soil, terrain, hydrography, vegetation, and climate) in scientific articles and state official agency.

The field research started by identifying the source of the Ligeiro river, located in the municipality of Araruna. Later, visits were carried out at the water collection points in the supply springs of the municipalities of Paranavaí, Umuarama, and Cianorte. In the case of Cianorte, fieldwork was carried out in the basins of the Bolivar stream and Ligeiro river, to checkpoints of degradation of the respective ecosystems, types of land use and occupation, and landscape potential. Therefore, a photographic record of the basins was carried out using a DJI Phantom 4 Pro V2 drone, at a height of $187.00 \mathrm{~m}$ (ideal distance found, between the drone and the surface, for quality and analysis of the photos). Also, photos from Sanepar's photographic archive were used to illustrate the siltation of the reservoir's dam and the turbid appearance of the water in rainy periods at the Raw Water Pumping Station (EEB1, in Portuguese) of the Bolívar stream.

Satellite images were obtained from Google Earth-Maps and Paraná Interativo in distant and difficult-to-access locations, in order to identify land use in the Ligeiro river basin survey of structures, works, and risk activities, such as rainwater drainage in the district of São Lourenço, in the municipality of Cianorte, directed to a tributary of the Ligeiro river; degradation of Permanent Preservation Areas - PPA; absence of ground cover; and pollution potential represented by the presence of cassava flour, highway bridge and poultry sheds. Such mechanisms were also used to illustrate the delimitation of the EPA in the Araras stream basin, in Paranavaí, Paraná state, and infrastructure issues in the Jabuticabeiras Park, installed within the EPA of the Piava river, in Umuarama, Paraná state.

The geographical aspects are represented by maps of lithology, soils, climate, hydrography, phytogeography, hypsometry, and delimitation of the basins of the Bolívar stream and Ligeiro river basins were elaborated based on vector files provided by the ITCG, in a 1:50,000 scale. This cartographic information was stored in a geographic database for later editing in the Geographic Information System (GIS). Using these vector files, they were next imported into SIG QGis 3.12.1, where there was a cut from the layer of areas of interest (the Bolivar stream basin and the Ligeiro river basin). Subsequently, thematic classes were colored, according to the legend proposed by the ITCG. Finally, the print layout for the representation of physiographic variables was generated.

\section{RESULTS AND DISCUSSION}

According to data from the Serviço Florestal Brasileiro (2018), which is supported by the Ministry of the Environment, the state of Paraná has nine EPAs whose territory covers an area of $10,502.65 \mathrm{~km}^{2}$ (Table 1).

Of the EPAs listed in Table 1, those on the Iraí, Piraquara, and Passaúna rivers stand out as they regulate the spaces of the watersheds of the supply dams and are contemporaneous with the creation of the Integrated System for Management and Protection of the Springs in the Metropolitan Region of Curitiba (RMC) managed by Territorial Planning Units (TPUs) which were created to legislate areas with the strong pressure of urban occupation and fragile from the environmental point of view (INSTITUTO DAS ÁGUA DO PARANÁ, 2010). 
Paraná has 14 municipal/inter-municipal EPAs, as it can be seen in Table 2, which was last updated in 2012, therefore it did not include the municipal EPAs of the Araras stream in the municipality of Paranavaí, and the Piava river, in Umuarama, which are sources of public supply in these municipalities (MINISTÉRIO DO MEIO AMBIENTE, 2019).

\section{EPAS in public supply springs in Paranavai and} Umuarama

The northwest region of Paraná has 61 municipalities and covers an area of 2,481,601.5 hectares (12\% of the state territory). The largest municipalities, in terms of population, are Umuarama, Paranavaí, and Cianorte. In most cities in the region, the public supply service occurs through surface water sources, including the three cities mentioned. In the case of Umuarama and Paranavaí, the watersheds of the public supply springs were protected through municipal EPAs some years ago, mainly because of the concern with water quality.

In the municipality of Paranavaí, the EPA in the Araras stream was created by Municipal Law No. 2.436/2003 and established the following objectives: restriction of the use and occupation of the land; management plan; Municipal Secretariat for the Environment and Tourism as the managing entity; creation of Advisory Board and prohibition of any type of waste disposal.

According to an interview with an Emater forest engineer, who is on the Management Board of this

Table 1. Paraná State EPAs, total area, creation act, and management conditions

\begin{tabular}{lllcc}
\hline Name & Total area & Creation Act & $\begin{array}{c}\text { Management } \\
\text { Plan }\end{array}$ & $\begin{array}{c}\text { Management } \\
\text { Council }\end{array}$ \\
\hline Passaúna EPA & 155.62 & Decree 458/91 & No & No \\
State Guaraqueçaba EPA & $1,741.40$ & Decree 1228/92 & No & No \\
State Escarpa Devoniana EPA & $4,147.86$ & Decree 1231/92 & Yes & No \\
State Guaratuba EPA & $1,993.68$ & Decree 1234/92 & Yes & No \\
State Serra da Esperança EPA & $2,045.15$ & Ordinary Law 9905/92 & No & No \\
Pequeno EPA & 73.62 & Decree 1752/96 & No & No \\
Iraí EPA & 107.43 & Decree 1753/96 & No & No \\
State Piraquara EPA & 89.77 & Decree 1754/96 & No & No \\
Verde River EPA & 148.12 & Decree 2375/00 & No & No \\
\hline
\end{tabular}

Source: MINISTRY OF ENVIROMENT (2019)

Table 2: Paraná municipal and intermunicipal EPAs and total area.

\begin{tabular}{lll}
\hline Name & Municipality & Total Area $\mathbf{( k m}^{\mathbf{2}}$ ) \\
Xambrê River Interm EPA (Umuarama) & Umuarama & 290.40 \\
Xambrê River Interm EPA (Xambrê) & Xambrê & 89.05 \\
Xambrê River Interm EPA (Cafezal) & Cafezal do Sul & 159.28 \\
Cidade Real de Guaíra Municipal EPA & Terra Roxa & 109.31 \\
Alto Paraíso Municipal EPA & Alto Paraíso & 682.75 \\
Altônia Municipal EPA & Altônia & 408.83 \\
Guaíra Municipal EPA & Guaíra & 170.21 \\
Icaraíma Municipal EPA & Icaraíma & 229.57 \\
São Jorge do Patrocínio Municipal EPA & São Jorge do Patrocínio & 307.73 \\
Xambrê Municipal EPA (Francisco Alves) & Francisco Alves & 99.62 \\
Xambrê Municipal EPA (Iporã) & Iporã & 203.57 \\
Iguaçu Municipal EPA & Curitiba & 39.68 \\
Passaúna Municipal EPA & Curitiba & 43.00 \\
Rio Velho Municipal EPA & São Mateus do Sul & 10.81 \\
\hline
\end{tabular}


EPA and one of the creators of the implementation of this protected area, the biggest challenge was to overcome the resistance of the landowners in the basin. The respondent stated that the EPA improved the services of soil conservation in the micro-basins and the conservation of Permanent Preservation Areas (PPAs). The resource comes from the Municipal Environmental Fund, consisting of fines, on lending from SANEPAR ( $1 \%$ of the company's revenue in the municipality), ecological ICMS (taxes), and other sources. However, the implementation of the EPA generated initial conflicts with the landowners in the basin, as it restricted the use and occupation of the land to practices EPA that may cause sensitive degradation to the environment.

According to the environmental manager of SANEPAR, located in the municipality of Paranavaí, Paraná state, who is also a member of the Management Council, before the creation of the EPA, the Araras stream basin was degraded, as there were problems in the conservation of contour lines and in the maintenance of the rainwater containment tanks, which directly influenced the increase in the turbidity of raw water. After the implementation of the EPA, the conservation of PPAs improved in the maintenance of contour lines and containment boxes. Furthermore, biodigester septic tanks are being implemented for the basin's residents and funded by SANEPAR, in a partnership with EMATER and the municipal government. For the interviewee, the main obstacle for the implementation of the EPA was overcoming the resistance of the owners of rural lots in the basin, due to organizing the use and occupation of the land.

On the other hand, in Umuarama, the EPA in the Piava river, which covers the city's water supply, was created in 1998, through Municipal Decree No. 050/98. In that year, the basin showed strong signs of degradation. In historical records, according to technicians from SANEPAR, the city's supply was interrupted seven times for more than 24 hours in 1998, affecting approximately 90,000 people, were left without water. This situation was caused by the heavy rains that fell in the city, mainly in April of that year, when the accumulated rainfall reached $493 \mathrm{~mm}, 150 \mathrm{~mm}$ in a single day. For
Celligoi and Duarte (2000), the average annual rainfall of Umuarama corresponds to $1,512.6 \mathrm{~mm}$, and specifically for April, it is $139.4 \mathrm{~mm}$. The consequence was the siltation of the water source, with the turbidity of the water reaching 6,000 NTU, which, on a day without rain, varies between 3 to 10 NTU.

The objectives of the Piava river EPA are to promote the protection of seasonal semideciduous forest ecosystems; control land use by establishing rational criteria for the occupation of the area, and protect water resources. The main challenges overcome in the creation, conservation, maintenance, and development of the Piava river EPA were the solution of existing conflicts in PPAs, legal reserve (LR), water, rural occupation area, land subdivision, urban occupation area, industrial, Environmental Education and Management Plan (ARENITO SOLUÇÕES AMBIENTAIS, 2013).

Considering the past anthropogenic interference in the Piava river basin and the implementation of the EPA for its protection, the Technical Operational Agent and SANEPAR representative in the Municipal Council for the Environment (CMMA) of Umuarama, state of Paraná, stated that the Piava river basin, before the EPA, in addition to serious soil conservation problems it also had swine farming without control and lack of treatment of the generated effluents; expansion of residential neighborhoods and their respective waste; uncontrolled use and inadequate storage of pesticides. Thus, the creation of the EPA regulated the use and occupation of the Piava river basin, guiding the users and public managers on the importance of conserving it to ensure the quality and quantity of water from the spring that supplies the population of Umuarama in the state of Paraná. This was not an easy process because of the resistance of the rural producers and the lack of interest from the population.

Despite the benefits, the respondent understands that the EPA faces management-related problems, as it does not have a Management Council yet, being chaired by the CMMA. Furthermore, it is necessary to review the Management Plan; register the EPA with the State Secretariat for the Environment. Also, there is a need for further sharing among those involved in the management. 
The representative of the Environmental Defense Association of Umuarama (ADEMA) at CMMA was also interviewed. She is a retired civil engineer and has known the basin of the Piava river for a long time where, before the EPA, there was a lowdensity riparian forest neither the existence of rules for land use and occupation and the access roads were unmaintained and landowners did not protect the contour lines. This situation changed with the implementation of the EPA, which promoted the reforestation of the riparian forest and fenced most of its area; land use and occupation came to rely on restrictive rules; the advance of the subdivisions was contained; septic tanks were installed in the homes of rural properties and maintenance was carried out on the access roads and containment boxes.

For her, the management of the EPA by CMMA resulted in a significant improvement, as it had more professionalism and less political influence from the government or the biggest user. This scenario was fulfilled only through the implementation of a technical committee that added a lot of knowledge value. However, the struggle to prevent real estate speculation from advancing into the Piava river basin is constant. The greater awareness and engagement of sectors of society (NGOs, Church, University, etc.) has undoubtedly pressured the Government to not only avoid degradation but also act for preservation. In addition, the interviewee stated that the EPA needs to be registered with the competent agencies and be properly legalized in an attempt to add even more resources through the ecological ICMS, as the only resource available to the EPA comes from the Municipal Environmental Fund, transferred by SANEPAR.

The last interviewee was the representative of Umuarama Mitra Diocesana at CMMA. He stated that before the EPAin the Piava river basin, the region had several problems, especially the inadequate implementation of urban subdivisions at the head of the headwaters of the Piava river's tributaries, which increased the number of inhabitants and, consequently, pollution. The implementation of the EPA, in the public interest, established rules for the exploitation of private properties, promoting a better awareness of public agents and society about the importance of protecting the public water supply basin of Umuarama. In addition, there was the maintenance of riparian forests; erosion; restriction to crops, and use of products that could contaminate the river. The achievement of these benefits occurred through a clash with the landowners in the basin, who did not agree with the restrictive measures, and it was even necessary to seek the courts to avoid non-compliance with the rules, especially regarding the subdivision of the land, as the pressure from the real estate sector was and remains constant.

The EPA was managed by a council, which proved to be inefficient for this purpose, and was replaced by the CMMA, whose challenge was to maintain what had been achieved and to continue the conservation of Piava river water and basin for the population security; reconcile the legitimate interests of the landowners and workers in the area, because of the subsistence and maintenance of their assets and convince the authorities to invest, compensating for the necessary restrictions suffered. Also, according to the interviewee, the work of the CMMA has been favored through partnerships with the Federal Institute of Umuarama and the State University of Maringá, in order to develop and guide sustainable production projects within the EPA. In addition, initiatives by civil society entities and the Public Power aiming at a greater and better understanding of the environmental balance, organizing ecological awareness events for this purpose.

Based on the information obtained from the interviewees, it can be concluded that the hydrographic basins of the Araras stream and the Piava river were degraded before the creation of the EPAs, representing a serious risk for the supply of the urban population of the municipalities and that, after these conservation units were created, there were several actions that promoted a significant improvement in the conservation of the basins and the quality of the water in these water resources.

According to the data collected in this article 
and corroborating the statement by Andreoli et al. (1999), the water supply basins need to be preserved and conserved as the quality and quantity of water depending on the way the use and occupation are managed in this hydrographic unit. It is also highlighted the importance of the entire vegetation in a natural condition which has the role of regulating the flows of water resources.

\section{Proposal for the creation of EPAs in the Ligeiro river basin}

The water system in Cianorte is supplied from the springs of the Bolívar stream, which supplies $71.40 \%$ of the population, and eight deep wells that supply the remaining $28.60 \%$ (ECOSOL, 2015). According to City Cianorte's Municipal Master Plan-PDM (2006), the current source of public supply, the Bolivar stream is going through two obstacles: a disorderly urban occupation and siltation of the river. Associated with these two problems, the grant flow is also affected.

The disorderly occupation of the basin's slopes promotes erosion and soil pollution problems, which negatively impact the river. As for silting, it affects the quality of raw water, especially in rainy periods, when the accentuated change in turbidity can even interrupt the water capture process resulting from the impossibility of treating it and, consequently, interrupting the water supply to the population.

The granted flow, which is $128.70 \mathrm{~m}^{3} \mathrm{~h}^{-1}$, is lower than the recommended one, which is $437.18 \mathrm{~m}^{3} \mathrm{~h}^{-1}$, but which is not officially released by the agency in charge of it. Consequently, the concessionaire that provides the supply service (Companhia de Saneamento do Paraná - SANEPAR) decided to search for a new source that would allow for meeting the estimated demand for a further period of at least 20 years. Among the surface springs analyzed, the Ligeiro river was chosen, with sufficient flow to reach and surpass the demand for the proposed period (ECOSOL, 2015). According to the reassessment of the Preliminary Technical study of the Engineering Project for the Expansion of the Water Supply System of Cianorte, contracted by SANEPAR, the deadline for replacing the Bolívar with the Ligeiro river is 2022.

The Bolivar stream has been the source of the public supply in Cianorte since the 1970s, being classified as a class 1 river according to SUREHMA Ordinance No. 019 of 1992. The hydrographic basin occupies an area of $24.35 \mathrm{~km}^{2}$, with a drainage area of $14.30 \mathrm{~km}^{2}$ (INSTITUTO DAS ÁGUAS DO PARANÁ, 2015) and is part of the hydrographic basin of the Ivaí river. Bolívar stream is born near the urban area of Cianorte (Figure 1), where the expansion areas by subdivisions are also registered.

The Ligeiro river hydrographic basin totals 775 $\mathrm{km}^{2}$ (Figure 1). It is also within the hydrographic basin of the Ivaí river. All watercourses in the Ivaí river basin, according to SUREHMA Ordinance (Superintendence of Water Resources and Environment) No. 019/92, belong to class 2, except for watercourses that are used for public supply, as well as their tributaries, which belong to class 1 , from its springs to the catchment section for public supply, when the area of this catchment basin is less than or equal to 50 (fifty) square kilometers (INSTITUTO DAS ÁGUA DO PARANÁ, 2016).

The spring of the Ligeiro river is located in the municipality of Araruna at an approximate altitude of 600 meters. In territorial terms, its basin is located in six municipalities: from the south and southeast, the municipality of Araruna, where the main springs of Ligeiro river are located; at east, the municipalities of Peabiru-PR and Terra BoaPR; at north and northeast, the municipalities of São Tomé-PR and Jussara-PR and at the west, the municipality of Cianorte, with $50.63 \%$ of the total area of the basin (BUENO, 2016).

The main types of land use in the two basins (Figure 1) are farming and pasture, totaling 34.4\% and $47 \%$ in Bolivar, and $59.3 \%$ and $16.6 \%$ in the Ligeiro river, respectively. Areas used for pastures in the Bolivar stream basin are more representative than in the Ligeiro river basin, occupying the areas of the upper stretch of the river. The Ligeiro river basin has a representative area of native forest, totaling $15 \%$, but these areas are concentrated in 


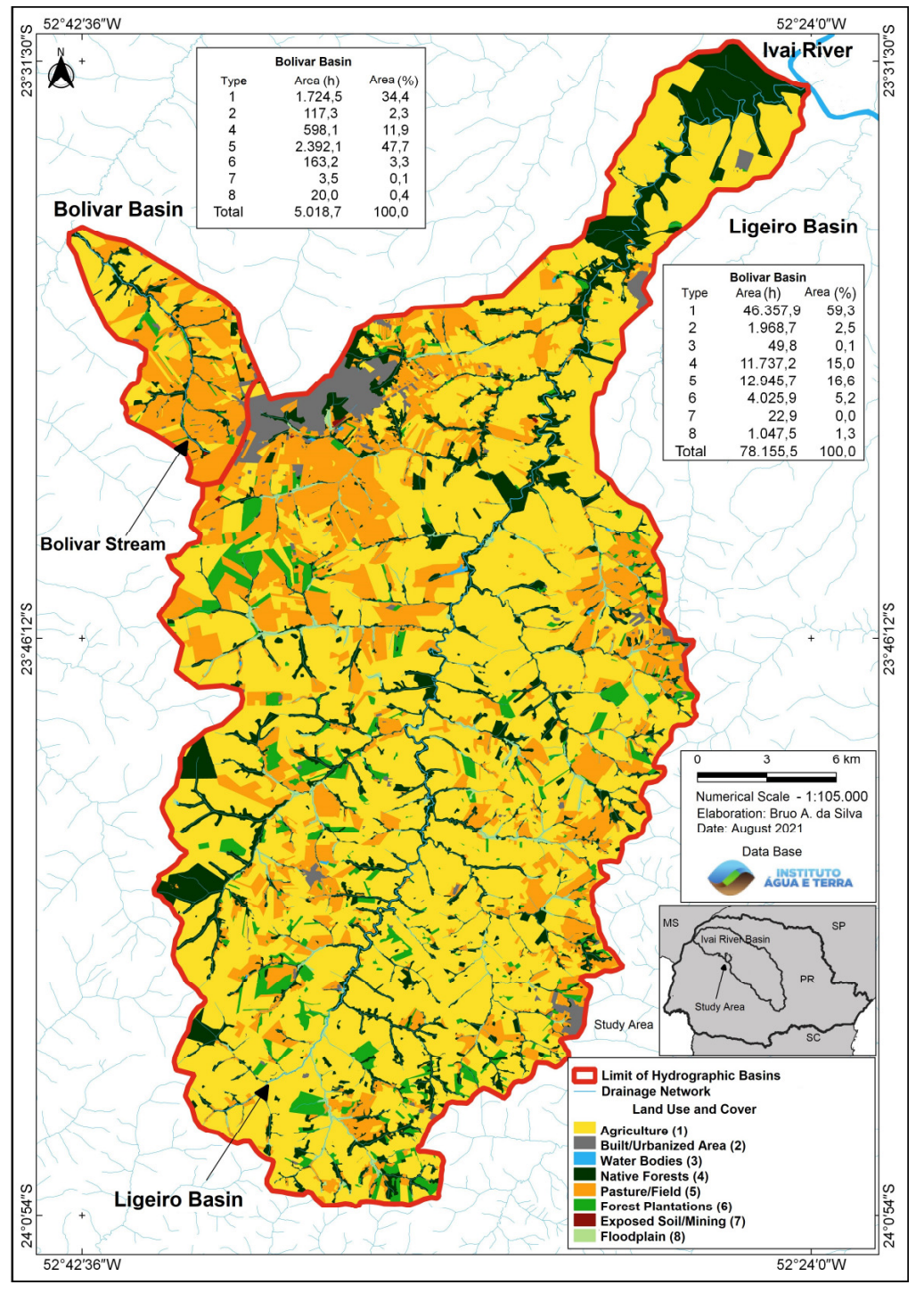

Source: The authors (2021)

Figure 1. Land use and occupation map of Bolivar stream and Ligeiro rivers basin, Cianorte-PR

the lower stretch of the basin, downstream from the capture point of the future spring. In the upper stretch of the Ligeiro basin, there is a predominance of agriculture and a small representation of native forest, which basically refer to areas provided for in the New Forest Code (BRASIL, 2012) as Permanent Preservation Areas - PPA and Legal Reserve areas.

The economic exploitation by intensive agriculture and pasture and not always within conservation management, as well as the nonconservation of PPAs, has caused soil degradation, with consequent erosion processes in both basins.

According to Lacerda and Figueiredo (2009), the absence of riparian vegetation affects the absorption of water from surface runoff in its surroundings, contributing to the formation of soil erosion processes. For Oliva Júnior (2015), this is a conflicting relationship, as the society attacks its habitat as a way to evolve its way of life, disregarding the damage caused by such evolution.

When mapping land cover and land use in the Peixe-Boi river basin area, in the northeast of the state of Pará, Pereira et al. (2016) observed in the PPA areas a considerable relationship between the preservation of natural vegetation and the maintenance of good water quality in the river basin. The authors emphasized that there is less 
surface runoff in areas of the arboreal vegetation class, which is as a result of greater soil cover, positively reflecting on water quality, with a reduction in the erosive process and soil leaching into watercourses.

Concerning Bolivar stream, according to Lacerda and Figueiredo (2009), the formation of erosive processes results in siltation of the watercourse, which can be seen mainly in rainy periods. Sand and clay carriage into the water source alters the level of the turbidity unit $(\mathrm{Tu})$ of the water, reducing "the efficiency of chlorination due to the physical protection given to microorganisms from the direct contact with disinfectants. In addition, turbidity particles transport absorbed organic matter that can cause the taste and odor" (BRASIL, 2014 , p. 92). The natural turbidity of waters is generally within the range of 3 to 500 turbidity units (Tu) for potability purposes (BRASIL, 2014). This variable in the Bolívar stream, on rainy days, can exceed 3000uT, inhibiting the water treatment process, which can affect the supply. According to Correia et al. (2008), turbidity can be defined as the measure of the difficulty of a light beam to cross a certain amount of water due to the suspension of particles. It is high in regions with more erosive soils, where rainfall may carry clay particles, silt, sand, rock fragments, and metallic oxides from the soil (BRASIL, 2014).

These situations are observed in the Bolivar stream basin, as it has places with no vegetation cover in the PPA, therefore promoting the formation of erosive processes. Such processes are enhanced by the fact that the watering of animals is carried out in the main river or its tributaries. Consequently, in rainy periods, the soil is carried into the river, altering turbidity, which is a parameter of the physical variable whose alteration is significant to the point of negatively influencing the process of water collection.

According to SANEPAR technicians, the increase in turbidity results in other problems, such as premature wear of the suction equipment; the need for constant discharges in the pipeline, flocculators, decanters, and filters, and; increased consumption of chemicals. As the cost of production is raised, the consumers have to pay for it, as a consequence.

Given such problems already faced in the current spring (Bolivar stream) and considering that the Ligeiro river has already been defined as a new public water supply source for Cianorte since 2022, it is understood that the Ligeiro river basin deserves special attention even before if such action takes place.

Therefore, considering that it is possible to prevent the same problems that affect the current spring of the Bolivar stream from occurring in the Ligeiro river, and in face of the examples of the Umuarama and Paranavaí EPAs, it was proposed the creation of two municipal EPAs in the upper stretch of the Ligeiro river (Figure 2), starting in the spring to the capture point of the future source (geographical coordinates $23^{\circ} 45^{\prime} 58.91^{\prime \prime} \mathrm{S}$ and $52^{\circ} 33^{\prime} 10.20^{\prime \prime}$ ), where Raw Water Pumping Station 2 (EEB2, in Portuguese) will be built.

Considering the municipal boundaries, two tributaries on the left bank of the Ligeiro river and their respective drainage basins are completely located in the municipality of Cianorte. In turn, the spring of the Ligeiro river and the tributaries on the right bank are located in the municipality of Araruna. There is also a tributary on the right bank whose drainage head is located in the municipality of Peabiru.

It is proposed to created two municipal EPAs as the river covers the municipality of Araruna. Thus, the EPA Quedas do Ligeiro I (Araruna) would be created on the left bank, with $209.76 \mathrm{~km}^{2}$, and the other, Quedas do Ligeiro II, with $219.82 \mathrm{~km}^{2}$, in the municipality of Cianorte (Figure 3 ).

In terms of environmental characteristics, the exutory area is located approximately at an altitude of 420 meters, indicating the altimetric amplitude of the area around 220 meters in relation to the springs. In general, the valleys are located within the 500-meter altimetry range. Thus, in the headwater sector of the Ligeiro river, the watershed is around 640 meters and the valley is around 500 meters, indicating amplitude of more than 100 meters. 


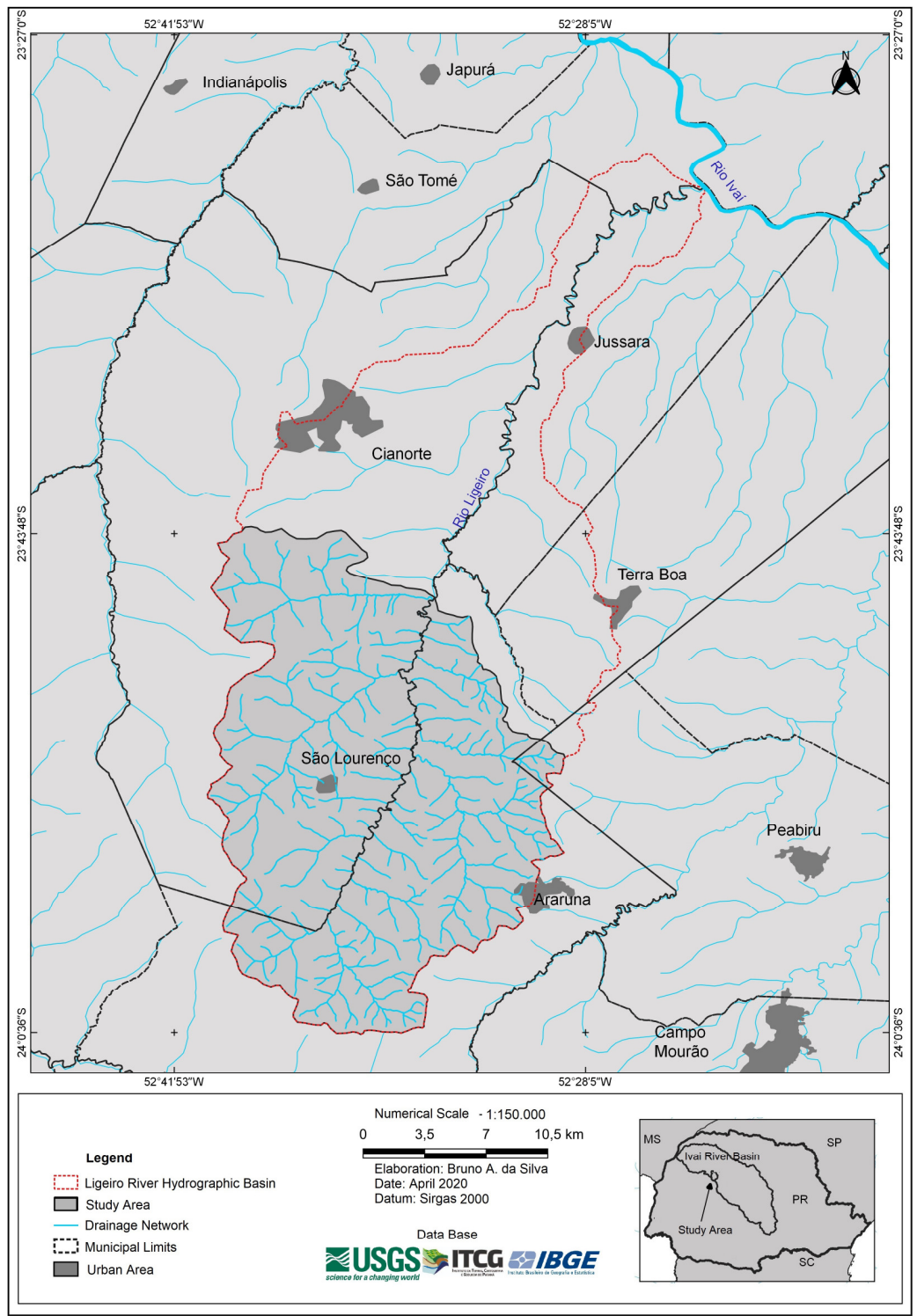

Source: The authors (2021)

Figure 2. Spring location in Ligeiro river basin

The predominant slope class is between $5.4^{\circ}$ and $10.8^{\circ}$, occupying the surroundings of the river and its tributaries, with isolated points ranging from $10.8^{\circ}$ to $18^{\circ}$ in the average slope, featuring an area with wavy and strong wavy terrain, respectively. The top presents a slope between $0^{\circ}$ and $5.4^{\circ}$, typical of a smooth undulating terrain (BUENO, 2016).

The Ligeiro river basin has the Caiuá Formation as its predominant geological structure, with sedimentary rocks that occupy almost the entire study area. The Serra Geral Formation, with basaltic rocks, appears only in adjacent areas along the river bed and its tributaries, especially those on the right bank of the river. This structure originated soils of the Ultisol, Oxisols, and Nitosol. The Nitosol and Argisol occupy adjacent areas along the Ligeiro river bed and its tributaries. The presence of Nitosol is more expressive upstream and on the right side of the river and Argisol downstream and on the left side. Oxisols, on the other hand, fill the remaining areas.

The situation and geographic characteristics of the basin allow us to verify that it facilitates the collection of water for supply, as observed in the SANEPAR reports (GEOCENTER, 2012). Therefore, it is worth highlighting some aspects 


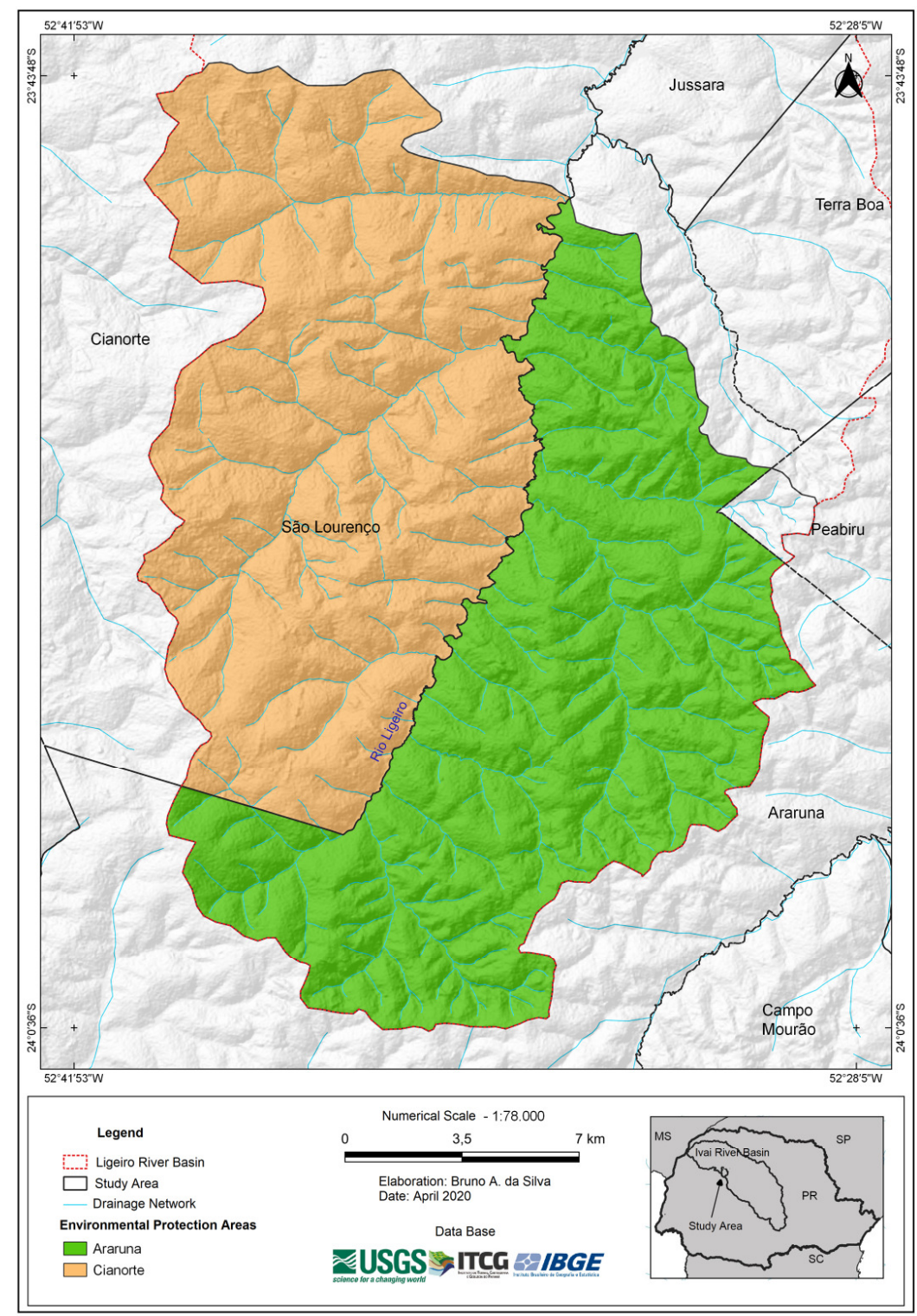

Source: The authors (2021)

Figure 3. Limit of EPA Quedas do Ligeiro I in Araruna and Quedas do Ligeiro II, in Cianorte

that should be considered precisely to avoid further problems, and this is how the proposal to create the EPAs can contribute.

The upstream from the catchment point, the Ligeiro river runs with a slope capable of contributing to the water flow (GEOCENTER, 2012), effectively contributing to the demand. On the one hand, this aspect facilitates the flow of water, but on the other, it can promote, according to Soares and Piroli (2019), the dragging of other materials into the water resource, such as soil, affecting the quality of the water and its capture.
Soil loss and silting of rivers are characterized as consequences of erosion processes and are the result of different forms of land use, as well as the characteristics of the terrain (SOARES; PIROLI, 2019). As in the case of the basin, the lithological substrate of the Caiuá Formation predominates, with soils that have a sandy texture, which naturally has natural susceptibility, care must be taken through conservation measures (BUENO, 2016), as soils with this characteristic are more subject to erosion (SILVA, 1995).

In relation to the soil, these aspects are one 
of many that can be foreseen in the conservation actions necessary in watershed areas. For that, the environmental management made through the EPAs model can become efficient up to the point of avoiding such problems, being even more important in springs whose hydrographic basin presents characteristics with natural susceptibility, as is the case of the Ligeiro river.

Magalhães and Barbosa Júnior (2019) state that treating water collected from a basin protected by a Conservation Unit is much different from treating water from an unprotected one, as the $\mathrm{CU}$ promotes the maintenance of water quality and quantity by ensuring continuity in the adequate conditions of the contribution basin, whose parameters related to production and water quality are guaranteed by this protection.

In this sense, the objective of the proposal to create the EPAs is precisely to anticipate further problems, in order to avoid or mitigate the consequences of the disorderly land use, serving the public interest in maintaining the quantity and quality of water available in the spring of the Ligeiro river, seeking participative management among the involved entities (Public Power, users, civil society) and being coherent with the local reality. The case of Araruna has not been studied yet, however, it is known that there is an important potential for actions of local interest on water management.

Pina and Ferreira (2010), when discussing the interface between the SNUC and the Water Law, highlighted the case of the Barra do Rio Mamanguape EPA, claiming that the results obtained during their work allowed to identify and highlight the great importance of the relationship between Conservation Units and the hydrographic basin and that in the specific case of the EPA, since it allows for sustainable use, it is essential to draw up a management plan, which can ensure the correct use of the area as well as the management of the existing natural resources, thus promoting the sustainability of the waters.

Regarding the maintenance of the quality and quantity of water resources, Brazil, particularly, the state of Paraná, is going through one of the worst water crises in history and issued ANA Resolution No. 77 (AGÊNCIA NACIONAL DE ÁGUAS
E SANEAMENTO BÁSICO, 2021) on June 1, 2021, which was ratified by the Government of the State of Paraná in Decrete No. 8299 of August 5, 2021 (PARANÁ, 2021), which declares a critical situation of quantitative scarcity of water resources in the Hydrographic Region of Paraná ${ }^{1}$ and claims that the scenario observed in this region is one of relevant water scarcity, caused by drought, which represents impacts on multiple uses of water. This implies restating the need to include conservation measures, such as the EPAs in public water sources, to promote the conservation of resources, the maintenance of reservoir and river levels, as well as the recharge of aquifers.

In addition to the direct issue in relation to water, the creation of EPAs as an environmental management tool could bring direct economic benefits to both municipalities, with the Ecological ICMS. The amounts generated can be reverted into benefits within the EPAs themselves, directly contributing to their financial management autonomy. In other words, the idea is to plan the use of natural resources sustainably, as advocated by many researchers, technicians, and professionals working in the environmental area. In the case under study, such measures would avoid problems already faced by the community. The culture of prevention is accessible and could certainly avoid the repetition of effects that contrary actions promote, as in the case of the Bolívar stream.

\section{CONCLUSIONS}

- The creation of Environmental Protection Areas can be seen as an important mechanism to promote environmental protection and conserve or improve local ecological conditions and ensure the well-being of human populations by disciplining the process of territorial occupation and ensuring sustainable use of natural resources.

\footnotetext{
${ }^{1}$ The Paraná Hydrographic Region covers seven states: São Paulo, Paraná, Mato Grosso do Sul, Minas Gerais, Goiás, Santa Catarina and the Federal District. It is the most populous and economically developed region in the country, with the greatest demand for water resources (AGÊNCIA NACIONAL DE ÁGUAS E SANEAMENTO BÁSICO, 2021).
} 
- The creation of EPAs benefited the springs in the municipalities of Paranavaí and Umuarama, besides being a fundamentally important alternative to be considered in the Ligeiro river basin, as a way to promote the conservation of the quality and quantity of water, to grow demand in the municipality of Cianorte.

- The creation of an Environmental Protection Area on the Ligeiro river will be an important mechanism to protect the landscape as well as the existing resources in the basin, especially to conserve the soil, which has an erosion potential classified as very high.

\section{AUTHORSHIPCONTRIBUTION STATEMENT}

SILVA, M.S.: Data curation, Investigation, Methodology, Project administration, Writing original draft; KREUTZ, C.: Formal Analysis, Validation, Writing-review \& editing; AZEVEDO, R.F.: Conceptualization, Supervision, Validation, Writing - review \& editing; MEZZOMO, M.D.M.: Conceptualization, Supervision, Validation, Writing - review \& editing.

\section{DECLARATION OF INTERESTS}

The authors declare that they have no known competing financial interests or personal relationships that could have appeared to influence the work reported in this paper.

\section{ACKNOWLEDGEMENTS}

This work was carried out with the support of the Coordination for the Improvement of Higher Education Personnel - Brasil (CAPES) - Financing Code 001. I would also like to thank the Professional Master's Program in the National Network in Management and Regulation of Water Resources -ProfÁgua, CAPES/ANA Project /AUXPE No. 2717/2015, and to the Federal Technological University of Paraná - UTFPR for their support.

\section{REFERENCES}

AGÊNCIA NACIONAL DE ÁGUAS E SANEAMENTO BÁSICO. Resolução ANA $\mathbf{n}^{\circ}$ 77, de $1^{\circ}$ de junho de 2021. Declara situação crítica de escassez quantitativa dos recursos hídricos na Região Hidrográfica do Paraná. Available in: file://D:/Documentos/Downloads/ Resolu\%C3\%A7\%C3\%A3o\%20ANA\%2077\%20 1\%20junho\%202021.pdf.

AGÊNCIA NACIONAL DE ÁGUAS E SANEAMENTO BÁSICO. As 12 Regiões Hidrográficas Brasileiras - Região Hidrográfica Paraná. Available in: https://www.ana.gov.br/as12-regioes-hidrograficas-brasileiras/parana.

ANDREOLI, C.V.; DALARMI, O.; LARA, A.I.; ANDREOLI, F.N. Os Mananciais de Abastecimento do Sistema Integrado da Região Metropolitana de Curitiba (RMC). Sanare, v.12, p.44-56, 1999. Available in: https://site.sanepar.com.br/sites/site. sanepar.com.br/files/SanareN12.pdf.

ARENito SOluÇÕES AMBIENTAIS. Plano de Manejo da APA do rio Piava. Município de Umuarama. Estado do Paraná. 2013. Available in: https://pt.scribd.com/document/375178067/ Plano-de-Manejo-Rio-Piava-2013-pdf.

BRASIL. Lei $\mathrm{n}^{\mathbf{0}} \mathbf{9 . 9 8 5}$, de 18 de julho de 2000. Regulamenta o art. $225, \S 10$, incisos I, II, III e VII da Constituição Federal, institui o Sistema Nacional de Unidades de Conservação da Natureza e dá outras providências. Brasília, 18 de julho de 2000. Available in: http://www. icmbio.gov.br/sisbio/images/stories/instrucoes_ normativas/SNUC.pdf.

BRASIL. Lei ${ }^{\circ}$ 12.651, de 25 de maio de 2012. Dispõe sobre a proteção da vegetação nativa; altera as Leis $\mathrm{n}^{\circ} \mathrm{s} 6.938$, de 31 de agosto de 1981, 9.393, de 19 de dezembro de 1996, e 11.428 , de 22 de dezembro de 2006; revoga as Leis $\mathrm{n}^{\circ} \mathrm{s} 4.771$, de 15 de setembro de 1965, e 7.754, de 14 de abril de 1989, e a Medida Provisória ${ }^{\circ}$ 2.166-67, de 24 de agosto de 2001; e dá outras providências. Brasília, 25 de maio de 2012. Available in: http://www.planalto.gov.br/ccivil_03/_ato20112014/2012/lei/112651.htm. 
BRASIL. Ministério da Saúde. Fundação Nacional da Saúde. Manual de controle da qualidade da água para técnicos que trabalham em ETAS. Brasília: Funasa, 2014.

BRASIL. Ministério da Saúde. Secretaria de Vigilância em Saúde. Manual de procedimentos de vigilância em saúde ambiental relacionada à qualidade da água para consumo humano / Ministério da Saúde, Secretaria de Vigilância em Saúde. Brasília: Ministério da Saúde, 2006.

BUENO, R. H. Aplicação do diagnóstico físicoconservacionista (dfc) da bacia hidrográfica do rio Ligeiro - Paraná. 2016. 106 f. Dissertação (Mestrado em Geografia) - Centro de Ciências Humanas, Letras e Artes. Programa de pósgraduação em Geografia. Universidade Estadual de Maringá. Maringá, 2016.

CIANORTE. Plano Diretor Municipal - PDM. Avaliação temática integrada. 2006. Available in: https://portaldosmunicipios.pr.gov.br/download/ public/arquivos/documentos/357/2018/04/03/ z8Nu86WOctgFLV3bdGOgKeqy3 YEZ680OJJkI. pdf.

CHUEH, A.M. Análise do solo e degradação ambiental na Bacia Hidrográfica do Rio Pequeno - São José dos Pinhais/PR, por meio do diagnóstico físico-conservacionista- DFC. 2004. 91p. Dissertação (Programa de Pós-Graduação em Geografia) - Setor de Ciências da Terra. Universidade Federal do Paraná.

CORREIA, A.; BARROS, E.; SILVA; J.; RAMAlHO, J. Análise da Turbidez da Água em Diferentes Estados de Tratamento. In: VIII ERMAC $8^{\circ}$ Encontro Regional de Matemática Aplicada e Computacional. 20-22 de nov. 2008. Universidade Federal do Rio Grande do Norte Natal/RN.

ECOSOL ENGENHARIA, SANEAMENTO E MEIO AMBIENTE. Projeto de Engenharia para Ampliação do Sistema de Abastecimento de Água de Cianorte. Volume I - Readequação do Estudo Técnico Preliminar, 2015.
GEOCENTER CONSULTORIA DE PROJETOS. Delimitação do rio Ligeiro na bacia do rio Ivaí. Volume I - II. Curitiba-PR, 2012.

GEOCENTER CONSULTORIA DE PROJETOS. Relatório Ambiental Simplificado (RAS). Rio Ligeiro, Bacia do Rio Paraná, Sub-bacia 64. Volume I - II. Curitiba-PR, 2012.

INSTITUTO ÁGUA E TERRA. Dados sobre as Unidades de Conservação. Available in: http:// www.iat.pr.gov.br/Pagina/Dados-sobre-Unidadesde-Conservacao.

INSTITUTO DAS ÁGUAS DO PARANÁ. Elaboração do Plano Estadual de Recursos Hídricos. Produto 1.1. Anexo I. Diagnóstico das Demandas e Disponibilidades Hídricas Superficiais (Definição do balanço entre disponibilidades e demandas). Revisão Final 2010. Available in: http://www.iat. pr.gov.br/sites/agua-terra/arquivos_restritos/files/ documento/2020-03/produto1_1_revisaofinal_0. pdf.

INSTITUTO DAS ÁGUAS DO PARANÁ. Plano das Bacias Hidrográficas do baixo Ivaí e Paraná 1. Curitiba-PR, 2016.

INSTITUTO DAS ÁGUAS DO PARANÁ. RTP1 - Relatório Técnico $n^{\circ} 1$ - Diagnóstico (Parcial): caracterização geral e regionalização do plano de recursos hídricos das bacias do Baixo Ivaí e Paraná 1. Consórcio RHA-FERMA-VERTRAG. 2015. Available in: http://www.iat.pr.gov.br/sites/aguaterra/arquivos_restritos/files/documento/2020-05/ rtp1_150615_final.pdf.

INSTITUTO ESTADUAL DO AMBIENTE (RJ). Atlas dos mananciais de abastecimento público do Estado do Rio de Janeiro: subsídios ao planejamento e ordenamento territorial. Rio de Janeiro, 2018.

LACERDA, D. M. A.; FIGUEIREDO, P. S. Restauração de matas ciliares do rio Mearim no município de Barra do Corda-MA: seleção de espécies e comparação de metodologias de reflorestamento. Acta Amazónica, v. 39, n. 2, 2009. 
MAGALHÃES, R. J. F.; BARBOSA JÚNIOR, A. R. O valor do serviço de proteção de mananciais. Associação Brasileira de Engenharia Sanitária e Ambiental. v. 24, n. 5, p. 1049-1060, 2019.

MARCOTTI, A. R.; MARCOTTI, T. C. B. Bacia Hidrográfica do Rio Ligeiro. In: ENCONTRO PARANAENSE DE PESQUISA E EXTENSÃO EM CIÊNCIAS SOCIAIS APLICADAS, II, 2011, Campo Mourão, Anais... Campo Mourão: Fecilcam, 2011, CD-ROM.

MINISTÉRIO DO MEIO AMBIENTE (MMA). Roteiro para criação de unidades de conservação municipais [recurso eletrônico] / Ministério do Meio Ambiente, Secretaria de Biodiversidade, Departamento de Áreas protegidas - Brasília, DF: MMA, 2019.

OKAWA, C. M. P.; ZUFFO, A. C.; DESCOVI, C. S.; ARAÚJO, A. A. Gestão participativa das partes interessadas em área de manancial: uma abordagem usando análise multicritério. Associação Brasileira de Engenharia Sanitária e Ambiental, 2021.

OLIVA JÚNIOR, E. F. Os impactos ambientais decorrentes da ação antrópica na nascente do rio Piauí - Riachão do Dantas/SE. 2015. 33p. Trabalho de Conclusão de Curso. Instituto Federal de Educação, Ciência e Tecnologia do Amazonas, 2015.

PARANÁ. Decreto $\mathbf{n}^{\circ} \mathbf{8 2 9 9}$, de 05 de agosto de 2021. Declara situação de emergência no Estado do Paraná, pelo período de 90 dias, tendo em vista a redução o volume de água disponível para captação para o consumo humano e dessedentação de animais, que teve como causa estiagem classificada como desastre, conforme Instrução Normativa $\mathrm{n}^{\circ} 2$, de 20 de dezembro de 2016, do Ministério de Integração Nacional. Available in: file:///F:/Defesa $\% 20$ do $\% 20$ Mestrado $/ 0508$ decreto $\% 20$ crise $\% 20$ $\mathrm{h} \% \mathrm{C} 3 \% \mathrm{ADdrica}$.pdf.
PARANAVAÍ. Lei n. 2436, de 24 julho de 2003. Cria a área de proteção ambiental do Ribeirão Araras e dá outras providências. Sistema Leis Municipais. Paranavaí, 2003. Available in: https://leismunicipais.com.br/a/pr/p/paranavai/ lei-ordinaria/2003/244/2436/lei-ordinaria-n2436-2003-cria-area-de-protecao-ambiental-doribeirao-araras-e-da-outras-providencias.

PEREIRA, B. W. F.; MACIEL, M. N. M.; OLIVEIRA, F. A.; ALVES, M. A. M. S.; RIBEIRO, A. M.; FERREIRA, B. M.; RIBEIRO, E. G. P. Uso da terra e degradação na qualidade da água na bacia hidrográfica do rio Peixe-Boi, PA, Brasil. Ambiente \& Água, v. 11 n. 2, 2016.

PINA, J. H. A.; FERREIRA, V. O. A importância da relação entre o sistema nacional de unidades de conservação e a política nacional de recursos hídricos: possibilidades para uma gestão integrada. In: XVI Encontro Nacional dos Geógrafos. Anais... Porto Alegre - RS, 2010.

\section{SERVIÇO FLORESTAL BRASILEIRO (SFB).}

Inventário Florestal Nacional: principais resultados: Paraná [recurso eletrônico] / Serviço Florestal Brasileiro. - Brasília, DF: MMA, 2018.

SILVA, M. S. L. Estudos da erosão. Ministério da Agricultura, do Abastecimento e da Reforma Agrária-MAARA. Empresa Brasileira de Pesquisa Agropecuária - EMBRAPA. Centro de Pesquisa Agropecuária do Trópico Semi-árido - CPATSA. Coordenadoria de Transferência de Tecnologia Agropecuária - CTTA. Petrolina, 1995.

SOARES, F. B.; PIROLI, E. L. Análise da hipsometria e da declividade da bacia hidrográfica do rio Pardo (São Paulo, Brasil) como subsídio para o planejamento ambiental da área. In: SIMPÓSIO BRASILEIRO DE GEOGRAFIA FÍSICA APLICADA, XVIII, 2019, Fortaleza. Anais eletrônicos... Fortaleza: Universidade Federal do Ceará, 2019. 


\section{SUPERINTENDENNCIA DOS RECURSOS HÍDRICOS E MEIO AMBIENTE (SUREHMA).} Portaria SUREHMA n $019 / 92$ de 12 de maio de 1992. Dispõe sobre o enquadramento dos cursos d'água da bacia do rio Ivaí. Curitiba, 1992. Available in: http://www.aguasparana.pr.gov.br/arquivos/File/ portarias/enquadramento_b_ivai.pdf.

TORRES, L. M.; SCHIAVETTI, A. A Gestão Participativa como Instrumento de Educação Ambiental nas APAs: o exemplo da APA Joanes Ipitanga. Revista TECBAHIA, Camaçari, v. 20, n. 1, 2005.

UMUARAMA. Lei 3796, de 20 de dezembro de 2011. Institui a Área de Proteção Ambiental - APA, da bacia de captação do Rio Piava, localizada no município de Umuarama, Estado do Paraná. Sistema Leis Municipais. Umuarama, 2011. Available in: https://leismunicipais.com.br/ a1/pr/u/umuarama/leiordinaria/2011/380/3796/ lei-ordinaria-n-3796-2011-institui-a-area-deprotecaoambiental-apa-da-bacia-de-captacao-dorio-piava-localizada-no-municipio-deumuaramaestado-do-parana? $\mathrm{q}=3796$. 